\title{
Radiological Monitoring
} Results for Groundwater Samples Associated with the Industrial Wastewater Reuse Permit for the Materials and Fuels Complex Industrial Waste Ditch and Pond: November 1, 2012October 31, 2013

Michael G. Lewis

February 2014

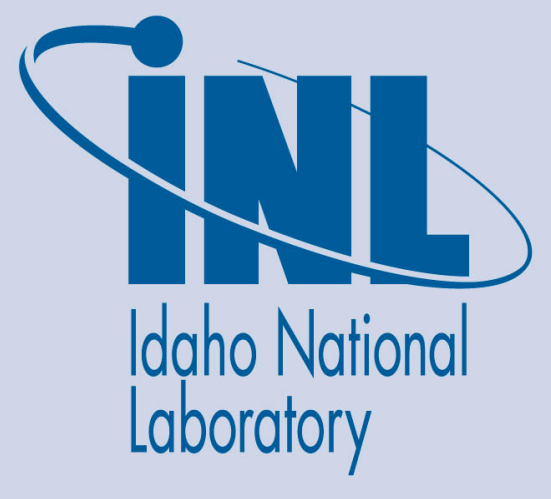

The INL is a U.S. Department of Energy National Laboratory operated by Battelle Energy Alliance 
INL/EXT-13-30966

\section{Radiological Monitoring Results for Groundwater Samples Associated with the Industrial Wastewater Reuse Permit for the Materials and Fuels Complex Industrial Waste Ditch and Pond: November 1, 2012- October 31, 2013}

Michael G. Lewis

February 2014

Idaho National Laboratory

Idaho Falls, Idaho 83415

http://www.inl.gov

Prepared for the

U.S. Department of Energy

Office of Nuclear Energy

Under DOE Idaho Operations Office

Contract DE-AC07-05ID14517 
Intentionally Blank 


\begin{abstract}
This report summarizes radiological monitoring performed on samples from specific groundwater monitoring wells associated with the Industrial Wastewater Reuse Permit for the Materials and Fuels Complex Industrial Waste Ditch and Industrial Waste Pond WRU-I-0160-01, Modification 1 (formerly LA-00016001). The radiological monitoring was performed to fulfill Department of Energy requirements under the Atomic Energy Act.
\end{abstract}


Intentionally Blank 


\section{CONTENTS}

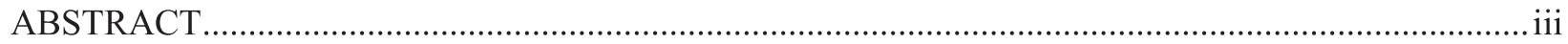

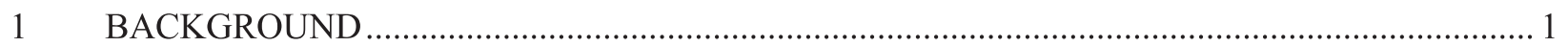

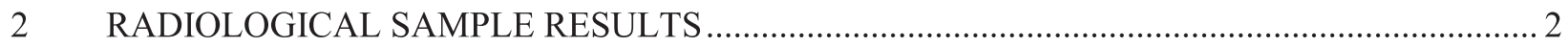

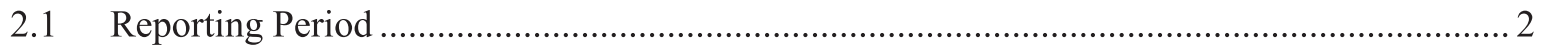

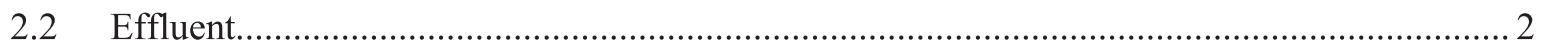

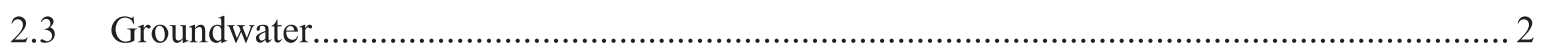

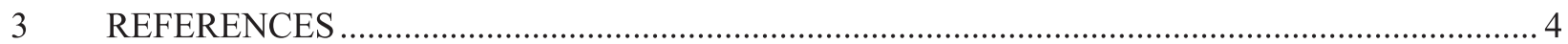

\section{TABLES}

Table 1. Positive detections in groundwater samples collected in April and September 2013 from the monitoring wells sampled for the MFC Industrial Waste Ditch and Pond IWRP. 
Intentionally Blank 


\section{Radiological Monitoring Results for Groundwater Samples Associated with the Industrial Wastewater Reuse Permit for the Materials and Fuels Complex Industrial Waste Ditch and Pond: November 1, 2012- October 31, 2013}

\section{BACKGROUND}

The radiological information presented in this report is provided based upon an agreement between the Idaho Department of Environmental Quality and the U.S. Department of Energy Idaho Operations Office. The agreement is documented in the Industrial Wastewater Reuse Permit (IWRP) WRU-I-016001 (formerly LA-000160-01), Modification 1, for the Idaho National Laboratory Site's Materials and Fuels Complex (MFC) Industrial Waste Ditch (IWD) and Industrial Waste Pond (IWP). The initial IWRP was issued in April 2010 (Neher 2010). Modification 1 was issued in June 2012 (Neher 2012). Items 7 and 8 of Section H ("Standard Reporting Requirements") of the IWRP state:

- The permittee agrees to provide to the Department the results of ground water radiological monitoring with respect to the MFC Industrial Waste Pond and Ditch hydraulic management unit (HMU) that is performed to fulfill Department of Energy requirements under the Atomic Energy Act. The permittee agrees to provide the results with the Annual Report.

- The permittee agrees to provide to the Department the results of radiological monitoring of the MFC effluent, prior to discharge into the HMU, with respect to the MFC Industrial Waste Pond and Ditch HMU that is performed to fulfill Department of Energy requirements under the Atomic Energy Act. 


\section{RADIOLOGICAL SAMPLE RESULTS \\ 2.1 Reporting Period}

For the MFC Industrial Waste Pond and Ditch, the 2013 reporting year runs from November 1, 2012 through October 31, 2013. As stated in the "Facility Monitoring Table" of Section G of the IWRP, groundwater sampling shall be conducted in April/May and September/October.

\subsection{Effluent}

Composite samples were collected monthly from the Industrial Waste Pipeline (WW-016001) over a 24-hour period. Grab samples were collected quarterly from the wastewater discharged to Ditch C from the Industrial Waste Water Underground Pipe (WW-016002). No radiological analyses are performed on samples collected at these locations.

\subsection{Groundwater}

Groundwater samples for radiological parameters were collected from aquifer wells ANL-MON-A012, ANL-MON-A-013, ANL-MON-A-014 in April and September 2013. The samples were shipped under full chain of custody to GEL Laboratories in Charleston, South Carolina, and analyzed for gamma spectrometry, gross alpha, gross beta, tritium, and alpha spectroscopy. Samples were collected to satisfy the surveillance objectives of DOE Order 450.1A, release objectives of DOE Order 458.1, and requirements for the Comprehensive Environmental Response, Compensation, and Liability Act.

Table 1 shows the positive detections in groundwater samples. Positive detections are considered measurements exceeding the instrument's minimum detection level and greater than two times the uncertainty. Alpha/beta activity, uranium-234, and uranium-238 all occur naturally and are not necessarily indicative of anthropogenic impacts. Cesium-137 is produced in nuclear reactors and nuclear weapons testing. However, the cesium-137 detection occurred in the upgradient well (ANL-MON-A-012) and is presumed a false positive. 
Table 1. Positive detections in groundwater samples collected in April and September 2013 from the monitoring wells sampled for the MFC Industrial Waste Ditch and Pond IWRP.

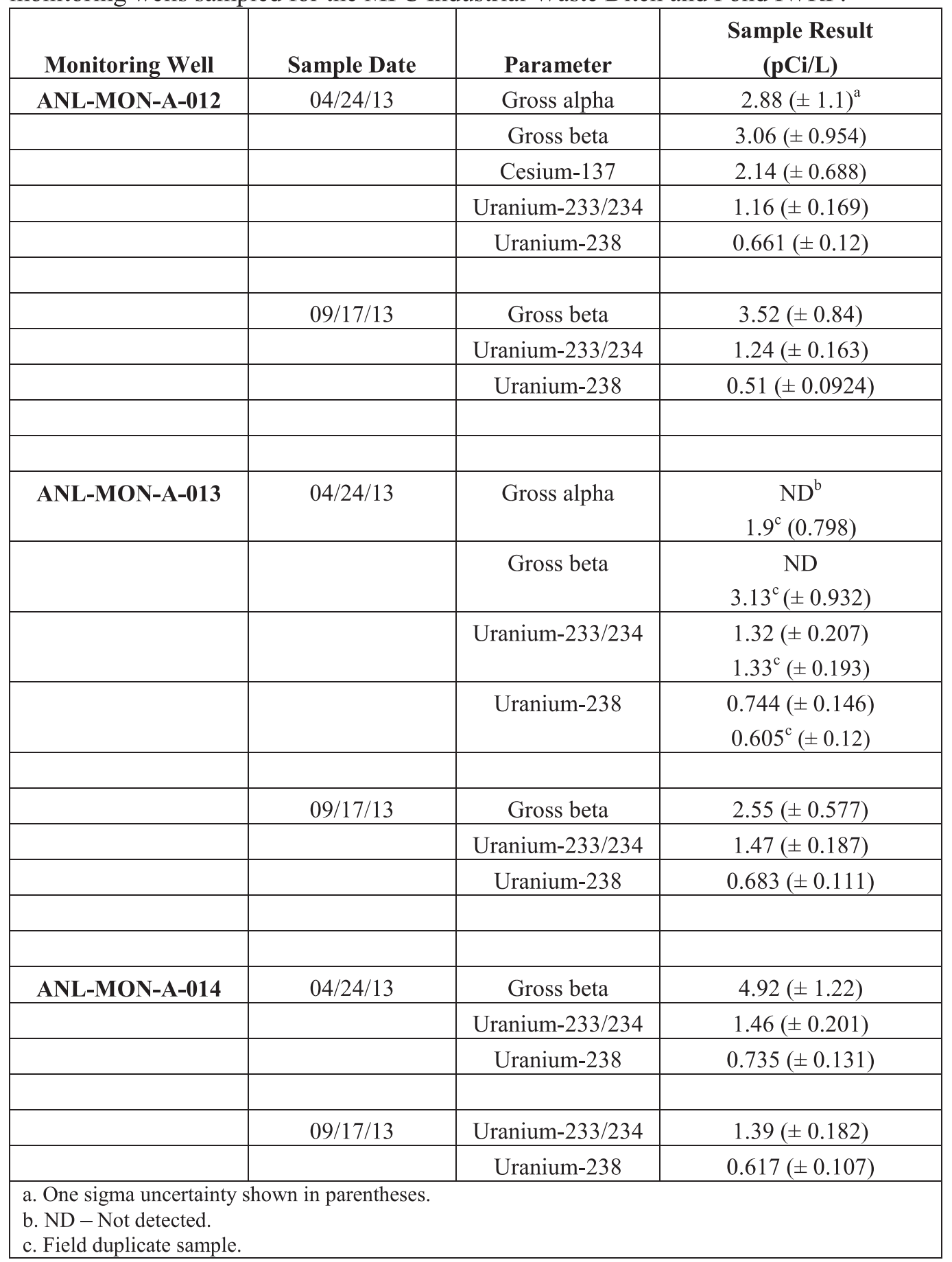




\section{REFERENCES}

42 USC § 2011-2259, 1954, “Atomic Energy Act of 1954,” United States Code.

DOE Order 450.1A, June 4, 2008, "Environmental Protection Program," U.S. Department of Energy.

DOE Order 458.1, February 2011, "Radiation Protection of the Public and the Environment," U.S. Department of Energy.

Neher, E., DEQ, to W. F. Hamel, DOE-ID, April 14, 2010, "Materials and Fuels Complex (MFC) Industrial Waste Ditch (IWD) and Industrial Waste Pond (IWP), Industrial Wastewater Reuse Permit No. LA-000160-01," CCN 220726.

Neher, E., DEQ, to W. F. Hamel, DOE-ID, June 21, 2012, "Materials and Fuels Complex (MFC) Industrial Waste Ditch (IWD) and Industrial Waste Pond (IWP), Industrial Wastewater Reuse Permit No. WRU-I-0160-01 (formerly LA-000160-01), Modification 1," CCN 227704. 